\section{ACRL Membership Meeting}

\author{
Meeting in Miami Beach \\ June 20, 1956
}

The ACRL Membership Meeting was held on Wednesday, June 20,1956, at the University of Miami in Coral Gables in the student cafeteria. The meeting followed the ACRL luncheon.

Mrs. Thelma V. Taylor of the Nominating Committee reported the election of the following officers: Vice-President and PresidentElect, Eileen Thornton; Director-at-Large, Mrs. Mary Manning Cook; ACRL Representatives on ALA Council, H. S. Brubaker, Natalie N. Nicholson, Helen Frances Pierce, and Elizabeth Opal Stone. (Unforeseen circumstances caused Miss Nicholson to resign the position immediately following election. The Board filled this vacancy by appointing Marietta Daniels for a one-year term.)

The following amendment to the ACRL Bylaws was presented by Mr. William Pullen, a member of the Committee on Constitution and Bylaws, and was unanimously adopted:

All of Article IV, Section 2, will be replaced by the following paragraph:

Standing committees shall be established with clearly defined areas of responsibility and with a specified number of members and specific terms of office. Committee memberships shall be staggered with regularity, in order to provide continuity. The vice-president (president-elect) shall appoint committee members to fill the vacancies due to occur during the term of his presidency; he shall also name the chairman of each committee. Special appointments to any committee may be made by the president for one year only. The vice-president (presidentelect) may waive his privilege of appointing the chairman and request the committee to elect its own chairman.

A rising vote of thanks was tendered to Mr. Hamlin, retiring executive secretary, and a resolution of appreciation recorded in the September issue of College and Research LIBRARIES, page 385, was unanimously adopted.-Arthur T. Hamlin, Executive Secretary.

\section{ACRL Board of Directors}

\section{Meeting in Miami Beach June 18, 1956}

Present were officers, directors and guests. President Vosper presided.

Mr. Parker as treasurer reported briefly on finances. Expenditures for the current year were well within the budgeted amount.

Members present had before them a document which gave the $1955 / 56$ budget, including estimated income and expenditure for that year, and a tentative proposed budget for $1956 / 57$. This had been prepared by Mr. Vosper, Mr. Parker, Mr. Weins and Mr. Hamlin.

In presenting the budget, Mr. Parker noted that the reorganization of ALA made financial planning very difficult. $\mathrm{He}$ noted that the budget had no estimate of income from surveys and similar activities; some income usually accrues from these sources. In regard to salaries, it was noted that the new executive secretary would begin at the first step of the grade. The travel budget was reduced because the new person probably would prefer to do little traveling early in the budget year. College and Research LIBRARIEs was being distributed to members during $1955 / 56$ for a total cost of approximately $\$ 4,700$ which was $\$ 1,200$ less than anticipated. The per member annual cost is considerably less than $\$ 1$.

A small cash balance was anticipated from the Monographs for the current year. Mr. Smith noted that very little publishing had been done but several numbers were about to appear. The proceedings of the two 1955 ACRL buildings institutes had just been published as No. 15; Charles Harvey Brown's Scientific Serials (No. 16) was in page proof. This very important work was the first Monograph to be issued in letterpress. No. 17 was to be the papers presented at the November, 1955, Conference of Eastern College Librarians at Columbia University, and manuscript was in the printer's hands. Nos. 18 and 19, both nearly ready for the printer, were Spoken Poetry on Records and Tapes, an 
index by Henry E. Hastings and Poole's Index Date and Volume Key by Marion V. Bell. Mr. Smith pointed out that the nearly 600 standing orders guaranteed a fairly large initial sale for any title published. The main problem was one of getting good manuscripts. All numbers are now in print. The Monographs had not been advertised this past year because it had no new titles; the new issues would be advertised.

On question, Mr. Hamlin pointed out that the travel of ACRL officers and staff was almost always charged to the travel item in the budget; ALA practice is to charge travel to the activity for which the traveling is done. He recommended that travel for the foundation grants program be charged to that budget item. Several directors favored an increase in the travel budget; it was agreed that this could be done later in the year.

Voted: to approve the ACRL Budget for $1956 / 57$.

It was noted that the salaries of two headquarters personnel are paid partly from the budget of the Monographs, partly from that of $C R L$, and partly from general funds. $\mathrm{Mr}$. Hamlin and Mr. Smith noted that the time spent on various activities varied widely, but the division of funds for these salaries seemed right for the present. The Monographs used less time than represented by charges during the past year, but during the coming fall would consume more time.

Voted: to approve the ACRL Monographs Budget for $1956 / 57$.

The budget for College AND REsearch Libraries was discussed. Mr. Tauber stated that costs increased each year and these increases required more revenue from advertising. He was distressed that he did not have more space for articles, as opposed to features. $C R L$ should have more advertising from publishers.

Reference was made to the opinion expressed on various occasions by ALA President Ralph Shaw that the journals were running the divisions into bankruptcy. Mr. Vosper stated that the Board had made firm decisions regarding the importance of the publications program. Whatever the situation of other divisions, ACRL was in good shape financially. Mr. Weins noted that nearly all of the manufacturing cost of $C R L$ was paid by advertising. This was not the case with other journals. Advertising revenue had increased 1000 per cent in seven years. Issues are increased in size in proportion to advertising support. It was assumed that $C R L$ would never show a profit because increased revenue was always used to increase service. Mr. Weins noted that the $A L A$ $B$ ulletin likewise increased pages for editorial matter in proportion to advertising revenue.

On query, Mr. Tauber stated that the $\$ 800$ allowed for his secretarial assistance was sufficient.

From 1939 through $1955 C R L$ had been printed by the Banta Publishing Company, which still handles the ALA Bulletin. With the January, 1956, issue the printing contract for $C R L$ was placed with The Ovid Bell Press, Inc., of Fulton, Mo. The Bell service is good and their charges considerably lower, according to Mr. Hamlin. The change involved one problem. The former printer was higher in most charges but low on reprints; the new printer charged the full cost for reprints. Therefore, the office had been paying part of the bill for $C R L$ authors who ordered reprints of their articles. The Publications Committee was requested to recommend policy on charges for $C R L$ reprints. (See action reported for the June 21 meeting.)

Voted: to approve the College AND RESEARCH LIBRARIES Budget for 1956/57.

Note: The budgets for the Monographs and $C R L$ are not printed here. They are incorporated in the monthly reports of the ALA Treasurer.

Mr. Orr presented the problem of appointing all members of all ACRL committees every year. Mr. Vosper agreed that this one task entailed enormous labor. The subject had been discussed at the midwinter meeting. Following the recommendation of the Committee on Committees, the Committee on Constitution and Bylaws had drafted a revision of the bylaws to allow committee appointments of several years' duration so that only a few members would complete their terms and be replaced each year.

Voted: to approve an amendment to the ACRL Bylaws as follows: All of Article IV, 
Section 2, will be replaced by the following paragraph:

Standing committees shall be established with clearly defined areas of responsibility and with a specified number of members and specific terms of office. Committee memberships shall be staggered with regularity, in order to provide continuity. The vice-president (president-elect) shall appoint committee members to fill the vacancies due to occur during the term of his presidency; he shall also name the chairman of each committee. Special appointments to any committee may be made by the president for one year only.

Mr. Thompson sought opinion on the practice of election of the chairman by the committee members. $\mathrm{He}$ suggested that the bylaw provide that "the president of ACRL may waive his privilege to the members of the committee, who may elect the chairman." Mr. Thompson wished the statement to be permissive, not mandatory.

Voted: to approve the following addition to the proposed amendment of Article IV, Section 2, of the ACRL Bylaws:

The vice-president (president-elect) may waive his privilege of appointing the chairman and request the committee to elect its own chairman.

Mr. Hamlin noted that this Board action on the amendment was for the guidance of the membership only. The bylaws may be amended only by a membership vote at annual conference or by mail.

The results of the recent election were announced. Natalie N. Nicholson and Marietta Daniels had been bracketed as candidates for ACRL representative on ALA Council. Miss Nicholson had won in a close election but had sent in her resignation before the votes had been tabulated. It was agreed that Miss Nicholson had been elected. Therefore, her resignation was to be accepted.

Voted: to appoint Miss Marietta Daniels to the position of $A C R L$ representative on $A L A$ Council created by the resignation of Miss Natalie $N$. Nicholson for one year only or until the next election.

Mr. Vosper stated that the ACRL Field of Interest Statement was largely acceptable to the Committee on the Implementation of the Management Survey, but one small change had been recommended for Board consideration-to insert the word "general" before the phrase "reference and research collections of significance." The statement would then read:

In the organization pattern of the American Library Association, the Association of College and Reference Libraries wishes to represent those libraries which support formal education above the secondary school level or which provide general reference and research collections of significance. It desires to carry on a program of activities to advance the standards of library services, in the broadest sense, in these libraries, and the continued professional and scholarly growth of those engaged in work therein.

The Committee suggested that this change would prevent overlapping with the Specialized Libraries Division. Mr. Orne felt that "general reference" would exclude such libraries as Linda Hall and Folger. Were these and similar institutions to be divorced from ACRL and assigned to the Division of Specialized Libraries?

Voted: to reject the proposal of the $A L A$ Council Steering Committee on the Implementation of the Management Survey to add the adjective "general" prior to the phrase "reference and research collections" in the ACRL statement of field of interest.

Mr. Branscomb noted that he could not attend the Board meeting three days hence. As a director or member of Council he had attended nearly all ACRL Board meetings during the past seven years, and he wished to express appreciation for the services of the retiring executive secretary. After sundry expressions of mutual esteem and good will by Board members and the secretary, the meeting was adjourned.

\section{Meeting in Miami Beach June 21, 1956}

This meeting was attended by committee chairmen as well as the usual Board members and guests. Mr. Vosper presided.

Mr. Bentz reported that the Statistics Committee had decided to offer reprints of the annual statistics at fifty cents each. He noted minor changes in the questionnaire. The committee was commended by the president for its accomplishments.

The Publications Committee (Mr. Orne reporting) wished to recommend a policy for 
$C R L$ reprint charges (see discussion at the June 18 meeting), which was endorsed in the following action:

Voted: to approve the recommendation of the ACRL Committee on Publications that the full cost of any reprints should be assessed against the purchaser; that is, a new scale of charges for reprints should be prepared and announced in terms which will at the least represent the full charge of the printer for the materials ordered.

Mr. Orne reviewed the work of the Publications Committee in selecting four research projects for support with United States Steel Foundation grants. The committee felt that support of research should be continued. Since the editor of the ACRL Monographs had resigned earlier in the year, an acting editor had been appointed. The committee had discussed qualifications and recommended three people for the editorship; the editor is appointed by the ACRL President. (Note: The acting editor, Rolland E. Stevens, was one of the three recommended and has accepted the invitation of President Vosper to become Editor of the ACRL Monographs.)

Mr. Dix reviewed the assignment of the Committee on Relations with Learned Societies. At its inception the committee had ruled out of consideration societies in scientific fields, professional associations, and educational associations. It had concentrated on possible relationships with the societies which are in the American Council of Learned Societies and the Social Science Research Council. These organizations had been very cooperative and appreciated the activities of librarians individually and collectively; it was doubted that many areas existed "in which formal joint activities would seem to be productive." Librarians are the custodians of scholarly materials and scholars are obviously interested in any efforts to improve access to these materials. Subject specialists and librarians might collaborate to reproduce more scarce material by microphotography. Bibliographic tools offered opportunity for joint work. ACRL might take leadership in preparing information on important accessions by libraries in the publications most used by scholars. Joint meetings of library groups and learned societies might be arranged; sections of learned societies might consider library-oriented programs. The committee, therefore, concluded:

1. That there exists in the learned societies great good will toward library groups and a desire to maintain a close working relationship with them.

2. That there are from time to time specific projects in which close collaboration with librarians would be of mutual benefit.

3. That special committees of librarians or standing committees dealing with specific activities might be an effective method of working on specific projects in collaboration with the learned societies.

4. That the executive secretary of ACRL might well make it his business to develop close and continuing personal relations with the executive secretaries of the various learned societies. Persons in this position in the various groups are in the best position to know of anticipated activities and to develop the mechanics of whatever action seems indicated.

5. That the limited investigation made by this committee indicates that similar committees might with profit explore the relations of library groups with the scientific societies, the professional organizations, and the educational associations.

On the recommendation of the committee, it was

Voted: to approve discontinuance of the ACRL Committee on Relations with Learned Societies.

Mr. Hamlin then spoke from his experience of the need for closer relationship with educational associations and certain professional organizations. During the past few months he had fruitful contact with the $\mathrm{Na}$ tional Association of College Stores, the American College Public Relations Association, the American Council on Education, and the NEA's Association for Higher Education. While much of this contact work must fall on the executive secretary, a committee was needed to operate in this area. ALA leaders felt that the reorganization would give ACRL a much better opportunity to work with other associations. He suggested the creation of a committee with the following purpose: 
To maintain liaison with selected groups which have joint interests; to keep informed on and cooperate with projects of mutual concern; as possible to provide information and advisory services on librarianship at conferences, for publications, and by correspondence to officers; to exercise general leadership toward the 1947 goal of development of relations with educational associations in the field of higher education. It is understood that the committee will depend on and cooperate closely with the ACRL Executive Secretary, who shall be an ex officio member.

Mr. Lyle said that the committee should be advisory to the headquarters office. It was

Voted: to establish an Advisory Committee on Cooperation with Educational and Professional Organizations.

Mr. Watson reported that the Committee on Recruiting had been active in four areas: articles on recruiting; cooperation with Alpha Beta Alpha; assistance to the Joint Committee on Library Work as a Career; and a pamphlet on library use for guidance counselors, which was then being prepared. The pamphlet was to be short and attractive and might sell for twenty-five cents. $\mathrm{He}$ hoped that 50,000 copies could be printed. The Board was doubtful that several thousand dollars should be invested in this.

Miss Herrick reported that the State Representatives had been busy in their respective localities. Katharine Stokes was responsible for a new membership promotion flyer for wide distribution.

Mrs. Crosland, chairman of the Buildings Committee, regretted that plans for an institute had collapsed.

The Committee on Rare Books was represented by Mr. Vosper, who reported their successful program earlier that day and some progress on a manual on rare books for the college library.

The Standards Committee was preparing for publication the library standards of the regional associations and of professional associations. Mr. Hamlin noted the important work done by the Public Libraries Division on standards and hoped ACRL would do the same in its field of responsibility.

$\mathrm{Mr}$. Hamlin outlined plans for distribution of grants to assist college libraries in the fall. He described his experience in seeking financial support for college libraries from the large corporations. Mr. Thompson suggested that corporations of regional importance should be contacted. He suggested Mr. Hamlin's experience and know-how might be passed on to others via a round-table procedure at some meeting. Mr. Hamlin hoped more librarians would present the ACRL program to assist college libraries to acquaintances in industry and to the larger corporations in their regions.

There had been no progress with the College Reading Proposal.

Discussion then turned to the problem of selecting a new executive secretary and his position in the reorganized American Library Association. A committee chairmanned by Mr. Orr had been set up to select the new person. Their slate of perhaps four to six names would be considered by the Board and the final selection made by the committee and Mr. Clift. Forty-five names had been considered, and at that time about one-half had been eliminated. There was much speculation and no definite information on the position of the new divisional secretary under the ALA reorganization. Mr. Hamlin felt there was not much hope of raising the salary $(\$ 7,050)$. It was

Voted: to approve the resolution in connection with the appointment of a new executive secretary, which reads as follows:

It is the sense of this Board that the Salary of the ACRL Executive Secretary must be substantially increased in order to secure the type of individual necessary to conduct our business properly, and that this be done even if reclassification is necessary.

The Board informally approved the following letter, drafted by Mr. Orne, to the dean of the School of Library Service of Columbia University:

Dear Dean Leigh:

In its recent annual meeting, the Board of Directors of the Association of College and Reference Libraries expressed its desire that I write you concerning your contribution to the strength of our Association.

For a goodly number of years, the School of Library Service of Columbia University has made its initial and certainly most important contribution to the success of our journal, College and Research Libraries, by making it possible for Dr. Maurice Tauber to continue to serve as 
Editor. As you surely know, we all believe that it is only through the contributions of Dr. Tauber and other members of the School of Library Service staff who have assisted him that the journal has attained its status among our professional journals. There is no really concrete way of representing the breadth and value of his personal contribution; we can only say that we are deeply grateful to him and to his administration for making it possible.

It gives me great personal satisfaction to write you for our Association on this subject. I am sure that my own pride in our journal is a true reflection of the feelings of our entire membership. Speaking for the membership and its Board of Directors, it is with pleasure that I send you our sincere appreciation of your continued interest and understanding.

Yours sincerely, /s/ Robert Vosper President

The grant of $\$ 30,000$ from the United States Steel Foundation was recognized by the following resolution:

The Board of Directors of the Association of College and Reference Libraries gratefully recognizes the many important and generous contributions of the United States Steel Foundation to the improvement of higher education through better financial support of college libraries, particularly:

1. Grants of $\$ 30,000$ in 1955 and again in 1956 for the improvement of college and university libraries. This support makes possible library tools and programs important to the educational process in scores of institutions.

2. The availability of these grants has assisted hundreds of librarians in the presentation of their needs to faculties and college administrations, and has greatly increased institutional understanding of the library's proper role in the educational process.

3. The Foundation has materially increased knowledge of library needs in foundation circles and, therefore, stimulated grants from other sources.

4. Through its wise and able executive director, the Foundation has rendered valuable assistance to this Association in the formulation of its program for the national support of college libraries, and in its presentation of the program to corporate foundations.

It is, therefore, our wish that the gratitude of the Association be recorded formally and be publicly acknowledged. The secretary is instructed to transmit this action to Roger $\mathbf{M}$. Blough, Chairman of the Board of Trustees of the United States Steel Foundation, and to W. Homer Turner, Executive Director.

This resolution was acknowledged later by Mr. Roger M. Blough, Chairman, Board of Directors, United States Steel Corporation, in a letter to Mr. Hamlin:

On behalf of my fellow Trustees of United States Steel Foundation, and personally, I wish to thank you and your Board of Directors for your very gracious resolution approving the cooperation extended by the Foundation to the Association of College and Reference Libraries.

I was especially interested in your statement that our Foundation's action has stimulated parallel action and interest on the part of other donors to the end of meeting the growing needs of your member libraries.

Mr. Turner has told me of your fine work in launching this project on a sound and expanding basis. I wish you every success in your further endeavors.

The Remington Rand grant of $\$ 5,000$ was formally recognized as follows:

The Board of Directors gratefully acknowledges the generous grant of $\$ 5,000$ for the purchase of equipment for college and university libraries from Remington Rand, a division of the Sperry Rand Corporation. This grant will materially assist a number of libraries in their services to higher education. It is also recognized as a public expression of confidence in the Association's program for the support of college libraries. The executive secretary is instructed to transmit to Remington Rand this expression of the Association's appreciation for this assistance to the college and university libraries of this country.

This was graciously acknowledged by Mr. Hal J. Syren, in charge of the corporation's Library Bureau.

On adjournment the Board expressed its appreciation for the services of the retiring executive secretary with suitable noise and a rising vote of appreciation, for which he was, and is, very grateful.-Arthur T. Hamlin, Executive Secretary. 


\section{News from the Field}

\section{Association of Southeastern RESEARCH LIBRARIES}

At Miami Beach on June 21, 1956, the Association of Southeastern Research Libraries was organized and launched on a program which may mark another important step in the notable interlibrary cooperative activity characteristic of the Southeast for twenty years and more. Recognizing the valuable contributions of A. F. Kuhlman to research librarianship, and his leadership in the Southeast, the group in Miami named him the first chairman of ASERL.

The purpose of the new association is to improve the resources and services of research libraries in the southeast region of the United States through cooperative effort. This was simply set forth at the time of organization: "The directors of research libraries in the Southeast agree to meet occasionally for the purpose of discussing problems common to their libraries." ASERL will, therefore, not be an operational body, but rather one concerned with informal and voluntary planning. It is frankly modeled on the Association of Research Libraries and, on a regional level, hopes to achieve among research libraries in the Southeast (on a smaller scale, of course, and in time, perhaps, to avert some of the problems which ARL might have solved more readily had the members been in closer touch with one another before they attained leviathan proportions) the benefits which have accrued to the major research libraries of the United States through joint effort. This regional association does not represent among libraries of the old Confederate States a bolt from the Union represented by ARL; quite the contrary, those ASERL members who are also members of ARL should henceforth be able to bring before ARL a much clearer understanding of the aspirations and problems of research libraries in the Southeast.

Membership, as well as organization, will remain flexible. Membership at the time of organization was largely confined to the libraries of universities in the Southeast (i.e., Alabama, Florida, Georgia, Kentucky, Louisiana, Mississippi, North Carolina, South Caro- lina, Tennessee, Virginia) which offer the doctorate; but to these were added the Oak Ridge Institute of Nuclear Studies Library, the Southeastern Interlibrary Research Facility, and the Virginia State Library -a total of 26 charter members. As other research collections, for example, state or public libraries, attain importance, they will probably be invited to participate. The assumption is, as in the case of ARL, that membership is institutional and institutions will, as a rule, be represented by their chief librarian or director. It is not contemplated that the meetings will be public or adorned by formal papers and speeches; but the proceedings of the meetings will be summarized for the record, and if judged by the group to be useful, copies will be distributed to all members. Tentatively, there will be five meetings each biennium-at the winter and summer meetings of ALA and at the biennial meeting of the Southeastern Library Association (which comes in the Fall of even-numbered years), where the ASERL Chairman will be elected.

It could be claimed that the formation of the Association of Southeastern Research Libraries is a normal development in the history of interlibrary association and cooperation of the South-highlighted by the founding of the Southeastern Library Association in 1922; the establishment of bibliographical centers in Chapel Hill, Nashville and Atlanta; the publication of Robert B. Downs' Resources of Southern Libraries (1938); and the organization of the Southeastern Interlibrary Research Facility (SIRF) in 1955. However, the direct line of events which culminated in the formation of ASERL at Miami Beach was set off by the specific and recorded suggestion of Robert B. Downs at the SIRF Council meeting at Georgia Tech on October 25, 1955. The minutes of that meeting contain this brief statement: "Mr. Downs remarked on the need for an association of Southern research libraries." SIRF had been wrestling with the problem of preparing a union list of serial holdings of southeastern libraries; and Guy R. Lyle devised a plan for a Southeastern Supplement to the Union List of Serials and its supplements, but the success of the plan required the cooperation of southeastern li- 
braries which were unwilling or unable at the time to join SIRF. Combining the suggestions of Downs and Lyle, the Director of SIRF, Richard B. Harwell, arranged a meeting between SIRF members and several librarians of other southeastern research libraries, held at the ALA Midwinter meeting in Chicago on February 2, 1956. Then and there, Benjamin E. Powell was asked to prepare for an organization meeting of the Association of Southeastern Research Libraries to be held at the Miami Beach meeting of ALA. This he did with some assistance from a committee which he appointed to advise him-Harlan Brown, Jack Dalton and Andrew Horn. At Miami, even as it was being organized, the ASERL gave tacit endorsement to SIRF's major project of a southeastern supplement to the Union List of Serials; and there was, in Miami, no indication that any major research library of the Southeast would not cooperate with SIRF in the compilation of a record of holdings of serials (published before December 31, 1949) not shown in the old Union List of Serials and its supplements. ASERL members are also agreed to report their holdings of new serial titles (published since December 31,1949 ) to the Library of Congress in time for inclusion in the first five-year cumulation of New Serial Titles.Andrew H. Horn, University of North Carolina.

\section{Acouisitions, Gifts, Collections}

Bowdoin College Library has received a four-volume set of the elephant folio edition of John James Audubon's The Birds of America. The donor is Roscoe H. Hupper of New York City, Class of 1907 and member of the Board of Overseers.

The California State Library has given approximately three thousand items to the School of Librarianship, Univeristy of California, Berkeley. Included are extensive files of annual reports, bulletins, catalogs, book lists, and handbooks of college, university and public libraries, together with some publications of early library schools. The collection supports the school's doctoral program, in addition to being a regional resource in the field.

More than two thousand valuable books concerning landscape architecture and related fields, including what may be the best pri- vate rare book collection on the history of the art of gardening, has been given to the University of California Library, Berkeley, by Mrs. Beatrix Farrand of Santa Barbara. A world-famed landscape architect, she and the late Dr. Max Farrand, former director of the Huntington Library and Art Gallery, San Marino, Calif., gathered the books over more than sixty years, giving special emphasis to the needs of scholar and teacher.

Two university libraries have received collections of first editions, political tracts, and memorabilia of George Bernard Shaw:

Kenneth Mackenna, executive story editor of Metro-Goldwyn-Mayer Pictures, has given such a collection to the University of California Library at Los Angeles. Bernard Burgunder of Wilkes-Barre, $\mathrm{Pa}$., has given a similar collection to the Cornell University Library.

Mrs. Mary Trent Semans has presented a distinguished collection of rare books and manuscripts on the history of medicine to the Duke University Medical School. Assembled by her late husband, Dr. Josiah C. Trent, this is regarded as one of the most notable collections of its kind ever brought together in this country by a single person. It ranges from classics like the famous Crummer first edition of William Harvey's De Motu Cordis (1628) to manuscripts by such great American physicians as Benjamin Waterhouse and Walter Reed. Named the Josiah C. Trent Collection in the History of Medicine, it will be housed in a special eighteenth-century room (also a gift of the donor) in the Medical School Library.

The State University of Iowa Library has received as a gift an extensive group of materials concerning the William $\mathrm{H}$. Ireland Shakespeare forgeries. Collected over a lifetime by the late Professor J. Hubert Scott of the English faculty, the collection offers great research potential due to its comprehensive nature. Numbering about 1,058 volumes, the collection contains practically all writings concerning the affair, as well as all publications of William Ireland.

Northwestern Library's Elzevir collection has been enlarged by some eighty volumes obtained from the University of Pennsylvania Library. Northwestern's holdings now total more than two hundred volumes. The wellpreserved copies present the characteristic El- 
zevir appearance: a few quartos and folios, but mainly pocket-size octavos, some slender, more of them squat, all minutely printed in Greek and Latin, adorned with varying printers' devices and an occasional engraved title page or frontispiece, usually bound in vellum.

The collection of Roxburghe Club Publications at the Ohio State University Libraries has been substantially completed by the purchase of approximately eighty volumes. This collection now lacks only six of the publications. The Roxburghe Club was founded in 1812, through the interest of Thomas Dibdin, on the occasion of the auction of the library of John, third Duke of Roxburghe. It is the oldest society of bibliophiles in existence.

A rare old French manuscript was presented to the University of Oregon Library by the Walter Woodard family of Cottage Grove, Ore. The manuscript is the "Geste de Montglane," an important item of the William Cycle of Old French epic poems. Dated about 1490, the manuscript comprises 229 vellum leaves, illuminated with colors and gold. It is in excellent condition, all pages being unstained and completely legible.

Chancellor Rufus B. Von KleinSmid has given the Von KleinSmid Library of World Affairs at the University of Southern California a copy of the Latin translation of Columbus' letter to Gabriel Sanchez, treasurer of Aragon, announcing his discovery of the New World. Regarded as a cornerstone for any American history collection, the work has been called "Americanum Number One."

The Stanford University Libraries have acquired about five thousand volumes, manuscripts, and personal papers of Bernard De Voto. This significant collection of Americana will greatly enrich the university's growing program in American studies. The manuscripts contain some work in progress, and publication rights in this remain with Houghton Mifflin.

\section{BUILDINGS}

Formal dedication of DePauw University's new million-dollar library took place on October 20. During a pre-dedication program, librarians from various parts of the country joined with Indiana college officials and DePauw students and faculty to evaluate the place of the university library. Dr. Stanley Pargellis, head of the Newberry Library, dis- cussed "The Student and His Reading." Robert Vosper, director of the University of Kansas Libraries, spoke on "The Place of the Library in a Liberal Arts College." The library, designed by J. R. Bailey of Orange, Va., represents the first tangible success in the Greater DePauw Program, a continuing development campaign.

A year-long, $\$ 400,000$ renovation of the Asa Griggs Candler Library, Emory University, is drawing to a close. Modernization of the thirty-year-old building includes: installation of an elevator; 14,000 square feet of additional space allowing seats for another 200 readers and shelf space for 75,000 more books; air-conditioning; improvements in the lighting and acoustics; and several new specialpurpose rooms. Made possible in part by a shift of the university administrative offices to a new building, this library project will effect better service in terms of open stacks, proper housing for special collections, and more pleasant environment.

The new library of the University of $\mathrm{Ha}$ waii, named for Dr. Gregg M. Sinclair, university president from 1942-1955, was dedicated early this year. Built with $221 / 2$-foot modules, the new library has space for about six hundred thousand volumes and eight hundred readers, more than twice the capacity of the old.

\section{Publications}

The Ford Foundation has appropriated \$1,735,000 to support and stimulate publication of scholarly books in the humanities and the social sciences during the next five years. . About thirty college- or university-sponsored non-profit publishing organizations are expected to become eligible for the foundation's grants. The determination of eligible university presses and of the amount of each grant will be made by the foundation with the assistance of an advisory committee composed of Chester Kerr, secretary, Yale University Press; Taylor Cole, professor of political science, Duke University; and Kerker Quinn, editor of Accent. At least 50 per cent of each grant is to be earmarked for books written by scholars located outside the institutions where eligible presses are located.

A secondary purpose of the foundation's program is to help relieve individual scholars of the financial burden of having to under- 
write publication of their works out of their personal funds.

The May, 1956, issue of the Law Library Journal is devoted to the celebration of the fiftieth anniversary of the American Association of Law Libraries. This golden jubilee issue contains a history of the association, its chapters, its publications, and its relations to other professional associations, as well as lists of officers, meeting places, photographs, and other information relating to the organization.

The unified Annual Report of the Libraries of the University of California, 1954-55, issued by the library council and prepared by its secretary, Dr. Lawrence C. Powell, and Betty Rosenberg of the UCLA library staff, contains, in addition to the usual statistics, a statement on "the why and how of selecting and using books in the state-wide libraries." University librarians will be interested in the discussion of the various forces that blend in building collections on the eight campuses of the University of California.

A Glossary of Terms Used in Microreproduction, by Hendrix TenEyck, has been issued by the National Microfilm Association (Hingham, Mass., 1955, 88p.). Librarians should find this a useful source of information for terms and definitions in the rapidly growing vocabulary of microreproduction.

Automation: Friend or Foe? by R. H. Macmillan (New York: Cambridge University Press, 1956, 100p., \$1.95) discusses the place of machines in modern life and touches on the use of computing machines for information processing.

Chapbook No. 2 of Beta Phi Mu is Fine Binding in America, by Elbert A. Thompson and Lawrence S. Thompson (Urbana, 1ll., 1956 , 45p., illus., \$2.50). Excellently designed by Ralph E. Eckerstrom, this is a study of the Grolier Club bindery and the people who gave it fame. Full documentation and extensive quotations from original sources may be found in a longer version of this study issued on microcards as The Club Bindery (Rochester, N.Y.: University of Rochester Press, 1954; ACRL Microcard Series, No. 14).

The Air University Periodical Index has issued a cumulative number, 1953-1955 (Vol. 6 , No. 4). Librarians may obtain copies of the index by writing to the director, Air University Library, Maxwell Air Force Base, Ala.
Books That Have Changed the World, by Robert B. Downs (American Library Association, 1956, 200p., $\$ 2.25$, cloth) has been enthusiastically reviewed in the library and literary press of the country. In his descriptions of sixteen examples in social science and the sciences, Dr. Downs shows the "immense power wielded by books." All librarians should have a copy of this book, which is also available as a "Mentor Book" of the New American Library, in paper-bound form for 35 cents.

Management's Documation Preview has been announced for publication. Planned for semimonthly issue, it will feature reproduction of contents pages of current periodicals and books in business and management. For further information and specimen copies write to Management's Documation Preview, Woodbury, N.J.

The Library Journal for June 15 is devoted to the problem of recruiting in libraries. In addition to a paper on "Improved Salesmanship" by Kathleen Stebbins, there are papers dealing with methods of recruiting.

The Germanistic Society of America (423 West 117th St., New York 27) has issued Recent Books on Modern Germany: List No. 1, History and Politics (New York, 1956, 7p.). The list is annotated.

Included in the Faculty Research Edition of the Savannah State College (Vol. 9, No. 2, October, 1955) is "A Study of the Community Services of the Libraries in the State-Supported Negro Colleges and Universities Approved by the Southern Association of Colleges and Secondary Schools," by M. G. Harrison, L. Hawkins, and A. M. Williams.

The Lost Cause Press, 2116 Confederate Place, Louisville $8, \mathrm{Ky}$., is reproducing in microcard certain scholarly works and texts in response to a request from the Committee on Microreproduction of the South Atlantic Modern Language Association. The first offering is Scheible's Das Kloster, published 1845 49. Full contents of Das Kloster are given on the Library of Congress card for the set. The price is $\$ 115$ postpaid.

Results of a recent survey of the extension activities of the Illinois State Library have been published as Occasional Paper No. 46 by the University of Illinois Library School. "Survey of Extension Activities of the Illinois State Library, May 16-31, 1956," will be sent 
without charge upon request to The Editor, Occasional Papers, University of Illinois Library School, Urbana, Ill.

\section{Miscellaneous}

The ALA Library Periodicals Round Table, sponsoring completion of a comprehensive "Directory of Library Periodicals," requests that editors of library periodicals send to John Harvey, State College Library, Pittsburg, Kan., four items of information: sponsoring organization, title, name of editor, and address. All library-sponsored periodicals are included.

Three chapters were added to the roll of Alpha Beta Alpha during the spring semester, 1956: $\mathrm{Mu}$, at Illinois State Normal University; $\mathrm{Nu}$, at Marshall College, Huntington, W. Va.; and Xi, at Iowa State Teachers College, Cedar Falls. This undergraduate library science fraternity now has sixteen chapters and more than one thousand members.

The second chapter of Beta Phi $\mathrm{Mu}$, national library science honorary fraternity, was installed at the University of Southern California early this year. Founded in 1948 at the University of Illinois to recognize high scholastic achievement, the fraternity has a total membership of over one thousand graduates of more than 28 library schools.

Marquette University, Milwaukee, is the seventeenth institution to participate in the Midwest Inter-Library Center. William B. Ready, recently appointed librarian at Marquette, will represent his institution on the MILC Advisory Committee of Librarians.

A grant of $\$ 375,000$ from the Carnegie Corporation is being used by Teachers College, Columbia University, to establish an institute for the study of higher education. Dr. Earl J. McGrath, former United States Commissioner of Education (1949-53), will head the Teachers College institute. A period of five years will be devoted to the studies, involving field surveys, of problems arising from the expansion of higher education. A similar institute will be set up at the University of California with Carnegie funds.

A workshop on library education will be held at the School of Library Science, Drexel Institute of Technology, Philadelphia, April 28-30, 1957.

A $\$ 25,000$ fund for the support and continued development of Princeton University's sixteen year old Graphic Arts Program, providing opportunities for extracurricular study in graphic arts and related fields, has been established in the university library by an alumnus whose life has been centered in printing and publishing. Carl W. Jones, class of 1911, formerly publisher of the Minneapolis Journal, has created the Elmer Adler Graphic Arts Fund in honor of the curator emeritus of the Library's Graphic Arts Division.

The Library Mart, a selective collection of equipment and supplies to be exhibited at major library conferences, is being launched by Helen T. Geer as a service to librarians and manufacturers. Its purpose is to give manufacturers-particularly the smaller ones -an opportunity to exhibit at these conferences, and librarians an opportunity to see and compare their products. Miss Geer, an authority on circulation systems whose interest in and knowledge of equipment and supplies made her a valued source of information to the whole profession while she was librarian at ALA headquarters, also plans to offer her services as a consultant. The address of The Library Mart is 227 Fairhope Avenue, Fairhope, Ala. 


\section{Duplicate Exchange Union of ACRL}

About 120 libraries, mostly small colleges belong to the ACRL Duplicate Exchange Union. They find that they get much valuable material just for the cost of transportation. Each member is expected to send out at least two lists a year, a total of about 240 lists.

Many libraries have found the union a wonderful way to save money on filling in gaps in their back files. Checking of the lists can be a simple matter, as most libraries allow the requester to simply circle the items desired. A few libraries want a written letter request. When the receiving library has gotten the material sent, they can simply cut out the address on the package and return that with the correct amount for postage.
One advantage of the union aside from the obtaining of backfiles and books is that libraries are making their duplicates available where they will do the most good. There is a great difference between the price received for duplicates and the price the library pays for them. This union is one way to cut out the middleman with his high profit.

The present Chairman of the Duplicate Exchange Union Committee, Charles Penrose, librarian of Clarkson College of Technology, Potsdam, N.Y., will be glad to accept applications for membership. A list of members is distributed each November. The rules of procedure as revised to January, 1954, are given below.

\section{Duplicates Exchange Union Rules of Procedure}

1. All types of duplicate lists may be sent. It is requested that periodicals, books, documents, etc., be listed separately, and that periodicals be listed by volume, number, and specific dates. Common weeklies (e.g. Life, Time, Saturday Evening Post) may be included.

2. Exchange lists should be restricted to completely free items, and exchanges should not be confined to a "piece for piece" basis.

3. Exchange lists should be sent simultaneously to all members and requests should be filled in order of receipt. Some exceptions might be made where one library owes another a great deal, or when one library especially needs certain issues to complete a set.

4. All members should make an attempt to send out at least two duplicate lists per year.

5. Each member may send out want lists.

6. Revised lists of members will be sent out annually.

7. Libraries wishing to join or discontinue membership in the union should notify the Chairman of the Committee. The changes will be incorporated in the next annual listing in November, and will not become effective until that time.

8. Notes on transportation costs:

a. First class mail is prohibitive.

b. Parcel post is usually cheaper than express for small packages. If package consists entirely of periodicals bearing the "entered as second class matter" statement, second class mail may be cheaper than parcel post.

c. Express may be cheaper than parcel post on larger packages. Mark express packages of "second class matter" periodicals: "Magazine rate."

d. Freight is cheapest, and should be used on large shipments.

e. In general, follow the shipping instructions of the receiving library, when given.

9. When refunding postage, libraries may save time by clipping the address label from the package and returning it with the postage, rather than writing a letter of acknowledgment. 


\section{Personnel}

JOSEPH S. KOMIDAR is now librarian of Tufts University, Medford, Mass. As university librarian he administers Eaton Memorial

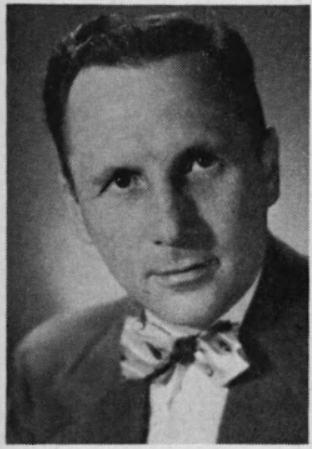

JOSEPH S. KOMIDAR Library, the central collection, as well as departmental libraries and special collections. He succeeded Raymond L. Wakley who retired after 28 years of service to Tufts.

Mr. Komidar did his undergraduate work at the University of Minnesota (B.S. in L.S., 1938; B.A., 1941), later earning two degrees at the University of Chicago (M.A., Education; M.A., Library Science). Before serving in the U.S. Army Air Force, he held reference posts at the University of Minnesota and Carleton College, Northfield, Minn.

In 1948 he became reference librarian at Northwestern University and in 1951 chief of reference and special services, holding that position until he left for Tufts. He was acting assistant librarian at Northwestern from December, 1955, to March, 1956. During the summer of 1955 he taught at the University of Denver School of Librarianship.

C. Sumner Spalding, now chief of the Serial Record Division in the Library of Congress, has been appointed chief of the Descriptive Cataloging Division. Mr. Spalding has been on the Library staff since 1940, except for a five-year period in military service during World War II. He received his B.A. and M.A. degrees from Harvard in 1933 and 1934, respectively, and received a B.S. degree in library science from Columbia University in 1940. That year he became an assistant in the Library's Music Division; on his return from military service in March, 1946, he joined the Descriptive Cataloging Division, where he held progressively more responsible cataloging positions. In 1949 he completed a five-month course in administrative training under the Civil Service Commission's Admin- istrative Intern Program. He was promoted from senior music cataloguer to assistant chief of the Catalog Maintenance Division in 1950, and from 1951 to 1953 he served as chief of the latter division. He has been chief of the Serial Record Division since April, 1953.

The position to which Mr. Spalding is now appointed has been covered in the recent past by Richard S. Angell, who served as acting chief of the Descriptive Cataloging Division in addition to his duties as chief of the Subject Cataloging Division. Mr. Angell is now taking leave from the Subject Cataloging Division until June 30,1957 , to pursue advanced studies in cataloging under a Rockefeller Public Service Award; during his absence, Leo E. LaMontagne, assistant chief of the Subject Cataloging Division, will serve as acting chief of that division.

LELAND S. Dutron is acting director of the Miami University Library, Oxford, Ohio. He received his undergraduate education at $\mathrm{Mi}$ ami University and his professional degree at Columbia (1932). From 1931-34 he was on the staff of the Genealogy and Local History Division, New York Public Library. He returned to Miami University in 1934 as chief of the circulation department, later being promoted to chief reference librarian which he remained until his present appointment. In 1955 he was made associate professor of "library science.

Lee Dutton is a past president of the Ohio Library Association, a contributor to professional journals, a participant in local radio

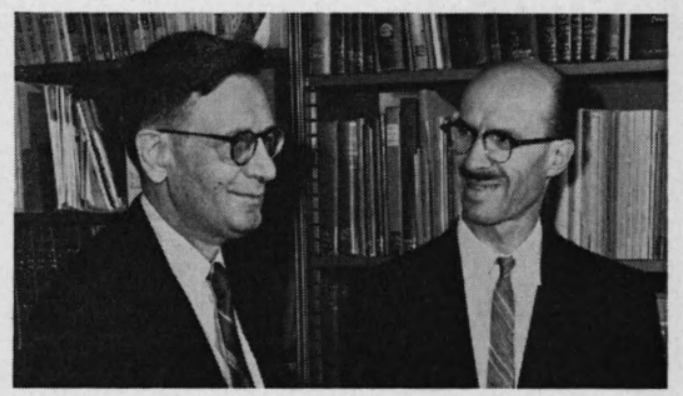

Edgar $W$. King, who has retired as director of libraries of Miami University, Oxford, Ohio, with Leland S. Dutton, new acting director. 
programs, an active member of the college and university section of the Ohio Library Association and of the library section, Ohio College Association.

Lee has a wide circle of friends among librarians and Miami alumni who, over the years, have grown to respect and admire his knowledge of his library's resources. Countless students and faculty members have turned to him for unfailing assistance. The present writer shares the happiness that this new opportunity brings to him.-J. H. Shera.

Charles Coleman Sellers is the librarian of Dickinson College, Carlisle, $\mathrm{Pa}$. $\mathrm{He}$ has been curator of the college collection of historical books and manuscripts since 1949 . $\mathrm{He}$ is a 1925 graduate of Haverford College and holds a master's degree in history from Harvard. Author of a biography of Charles Willson Peale, he has written biographies of Benedict Arnold, Lorenzo Dow and Theophilus Gates. $\mathrm{He}$ is a frequent contributor to journals dealing with American history and art.

Robert D. Harvey is the chief of reference and special services at Northwestern University. Mr. Harvey was assistant director in charge of public services for the University of Vermont Library. His bachelor's degree was earned at Wesleyan College and his master's degree in library service at Columbia University. In his new post Mr. Harvey will coordinate the library's principal departments in the broad fields of the humanities and social sciences.

Simeon J. Bolan, formerly Russian Bibliographer and consultant in Slavic acquisitions at Columbia University, has organized the Slavia Book Company, 115 University Place, New York 3, N. Y. His service includes ordering old and new Russian and other Slavic materials from abroad; catalog entries are to be furnished with titles ordered.

\section{Appointments}

Donald V. Black is physics librarian, University of California, Los Angeles.

Robert E. Burton is librarian for the Linde Air Products Co., Tonawanda, N.Y.

Mrs. Mary Duncan Carter is visiting professor of library science, University of Michigan.

David V. ERdman is editor of the New York Public Library publications.

ETHeL M. FaIR is acting librarian at Vassar College.

William Fitzgerald, director of the library school, George Peabody College for Teachers, is on a two-year leave-of-absence to serve as librarian of the International Cooperation Administration in Taipei, Formosa.

HERBERT Fock LER is assistant chief, Government Publications Section, Serials Division, Library of Congress.

Harold D. Gordon is administrative assistant, Cornell University Library, assigned to work on the library's building program. He was formerly assistant reference librarian, University of Miami, Coral Gables, Fla.

Frances L. Goudy is reference librarian, Ohio Historical Society. She was with the Grosvenor Library, Buffalo, N.Y.
Mrs. Helen Harrison is librarian of Mary Baldwin College, Staunton, Va.

Scott Kennedy is librarian of Phillips Petroleum Co. at the AEC Reactor Testing Center, Idaho Falls.

PEgGY KLINe is catalog librarian, Emory University.

MAURICE LEON is associate librarian and instructor in legal bibliography at the University of Wisconsin Law College.

W. KENNETH LOWRY is manager of technical information libraries at Bell Telephone Laboratories.

Marvin Lowenthal is director of special services, Brandeis University, Waltham, Mass.

David K. MaxfieLd, former librarian of the Chicago Undergraduate Division, University of Illinois, is assistant to the director of the University of Michigan Library.

WILHELM Moll is first assistant documents librarian, Indiana University.

RUTH HUNT MORRIs is acquisitions librarian, Johns Hopkins University.

Vivian C. Prince, head of technical processes, University of Florida Library, has been awarded a Fulbright lectureship at the University of Dacca, East Pakistan, for 1956-57. 
RICHARD C. Quick is assistant to the librarian, University of Delaware.

ROBERT S. TAYLOR, assistant librarian of Lehigh University, has received a Fulbright lectureship in library science at Delft Technological University for 1956-57.

EVERETt M. Wallace is assistant engineering librarian, University of California, Los Angeles.

Washington University Libraries, St. Louis, Mo., announce these appointments: JoHN Dustin, assistant chief, reference department;
RICHARD JoHnson, assistant chief, circulation department; MARJorie KarLson, chief, reference department; JoHN MCDONALD, assistant to the director; MARGERY MEYER, assistant serials librarian; and MARY Elizabeth WADE, reference assistant.

Mrs. Shirley Wayman is chief circulation librarian, Emory University.

L. KenNeth Wilson is geology librarian and departmental library coordinator, University of California, Los Angeles.

\section{Retirements}

On August 1, 1956, Edgar Weld King retired as director of libraries, Miami University, Oxford, Ohio, after holding this position for 34 years; but his friends are confident that he is not retiring from the profession.

When he went to Miami University in the fall of 1922, he found a heterogeneous collection of some fifty thousand volumes. $\mathrm{He}$ left it with over three hundred thousand volumes admirably and painstakingly selected. He developed one of the finest collections of Ohio Valley history available in the region, the definitive collection of McGuffey readers and one of the finest collections of early children's books in the nation.

Few librarians know their bibliographic resources as thoroughly as Ned King and this writer has never met one more competent in reference work. During a period of his service at the New York Public Library, Isadore Gilbert Mudge referred to him as "a library ghost [because he] haunted the stacks until he found the answer." Certainly he knew no eight-hour days nor forty-hour week and the writings of countless Miami students and faculty were enriched by his services.

Ned King should not be permitted to withdraw into retirement. The profession has a right to share in the harvest of his years of service. We know of at least one library school that badly needs the insight, knowledge and wisdom with which he is so richly endowed. We wish for a younger generation some intimation of the experience we have had the good fortune to enjoy.-J. H. Shera.

Mrs. Frances Carhart retired as head of technical services, Drake University, Des
Moines, Iowa, where she had served since 1927.

Arthur H. Cole retired as Harvard University Business School librarian and professor of economics.

Ruby Ethel Cundiff, professor of library science at Madison College, Harrisburg, Va., since 1948, retired after 46 years as librarian and teacher. She was formerly on the library school faculties of George Peabody College and Syracuse University. Her Manual of Techniques and lists of recommended reference books have been widely used in elementary and high school libraries.

Orrena Louise Evans retired from the librarianship of the U.S. Bureau of Roads. She developed a classification for highway engineering literature and served as first editor of Public Affairs Information Service.

Julian S. Fowler is retiring as librarian of Oberlin College, a post he had held for 28 years. Early in his career he was librarian of the University of Cincinnati.

Edward A. Henry, librarian emeritus of the University of Cincinnati, has retired after five years service with the Joint University Library, Nashville, Tenn., and the Peabody Library School. However, he will serve in the catalog department of the University of $\mathrm{Mi}$ ami (Fla.) until February 1957.

Herman Ralph Mead, bibliographer, retired after forty years service at the Henry E. Huntington Library, San Marino, Calif.

MAY MoRris, librarian of Dickinson College, Carlisle, Pa., retired with the rank of professor emerita of library science.

Marguerite E. Putnam retired after 35 years as chief acquisitions librarian at the 
University of Washington. She was largely instrumental in establishing and supervising the acquisitions procedures that have raised the University of Washington Library to its present rank. Miss Putnam was active in committee work for the Pacific Northwest Library
Association and the ALA.

Gertrude M. Sullivan retired after 43 years in the Harvard College Library. During recent years she headed the order and accounting section of the acquisition department.

\section{Necrology}

Charles Wesley Smith, whose death was noted in the September issue, had been associated with the University of Washington

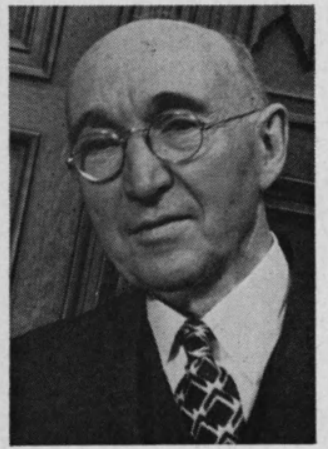

Charles W. Smith since 1905. When he retired in 1947, after 42 years of active service, the Board of Regents appointed him professor and librarian emeritus and bibliographic consultant. He fulfilled his duties as bibliographic consultant almost up to the time of his death.

Born in Elizabeth City, N. C., on June 20,1877 , and reared east of the Mississippi, Mr. Smith devoted his entire professional life to the Pacific Northwest. He came to the University of Washington Library in 1905 immediately after graduation from the University of Illinois Library School. He served as assistant librarian from 1905 to 1913; associate librarian from 1913 to 1929; and as chief librarian from 1929 to 1947.

When he joined the University of Washington Library staff, Mr. Smith found a small collection of twenty thousand volumes housed in the loft of an old building. At the time of his retirement the magnificent Henry Suzzallo Library Building contained more than six hundred thousand volumes. The unusual ornamentation of the glass in the great windows of the reference room is a reminder of Mr. Smith's keen interest in the book arts. He recommended to the architects that early watermarks be used as designs, and his felicitous suggestion was admirably carried out.

In $1923 \mathrm{Mr}$. Smith was commissioned by the university to visit various European countries in search of important sets of periodicals and publications of learned societies. He pur- chased more than nine thousand new books and over ten thousand pamphlets. He established fine personal relations with European dealers which even today pay rich dividends to the university.

Mr. Smith was never one to be contented with merely administering the rapidly growing university library. At heart he was first and foremost a bibliographer par excellence. In 1909 he published a checklist of PacificNorthwest Americana. This proved so valuable to bookmen that, in 1921, he was encouraged to bring out a more extensive edition. The new edition listed material on the history of Washington, Oregon, Idaho, Montana, British Columbia, Alaska, and the Yukon. The work attracted wide attention, and became an indispensable guide to the literature of the region.

Besides Pacific Northwest Americana, Mr. Smith was author or compiler of many important bibliographical works and contributions to professional journals. He served as business manager of the Pacific Northwest Quarterly from 1913 to 1935.

Within the library profession Mr. Smith will long be remembered as one of the leading librarians of the country. He was early elected a fellow in the American Library Institute. $\mathrm{He}$ was an active member of the American Library Association, the Pacific Northwest Library Association, in which he served as president from 1919 to 1920, the Bibliographical Society of America, and the American Historical Association. He was known to hundreds of graduates of the University of Washington School of Librarianship for his fine courses in bibliography and reference. He was admitted to the faculty in 1913, and in 1926 he was promoted to the rank of full professor.

Partly because of his extensive bibliographic work, Mr. Smith early sensed the importance of library cooperation and collaboration. He served as chairman of the Bibliog- 
raphy Committee of the Pacific Northwest Library Association from its establishment in 1917 until the time of his retirement. Recognizing the need for better research tools, he rallied fellow librarians to organize a bibliographic center for the Pacific Northwest. In 1940 his persistent efforts culminated in signal success with the granting by the Carnegie Corporation of $\$ 35,000$ for the establishment of the center. Today, the Pacific
Northwest Bibliographic Center stands as an enduring monument to his genius and the crowning achievement of his work on behalf of librarianship in the Pacific Northwest.Harry C. Bauer.

Mrs. EleANor A. BANCroft, assistant to the director of the Bancroft Library, University of California at Berkeley, died August 28, 1956, after a long illness. She was associated with the library for more than 35 years.

\section{Foreign Libraries}

Arundell Esdaile, formerly secretary of the British Museum Library, died June 22, 1956, at the age of seventy-six.

Alicia Perales OJeda is professor of organization and administration of libraries for the new graduate library school, Universidad Nacional Autonoma de Mexico.

JORIS VORSTIUs retired as editor-in-chief of
Zentralblatt für Bibliothekswesen. His successor is Werner Dube.

EFrain Rojas Rojas is director of the Biblioteca Central de la Universidad de Costa Rica in San José.

Lauri O. Th. Tudeer, librarian of the University of Helsingfors from 1933 to 1954, died last year.

\section{Harwell to Be ACRL Executive Secretary}

Richard B. Harwell has accepted an appointment as ACRL Executive Secretary. He is now head of the Publications Division of the Virginia State Library and will take over his new duties on March 1, 1957. He will also be at ALA headquarters for a short time before and during the Midwinter conference.

A biographical sketch of Mr. Harwell appeared on page 179 of the March issue of CRL and his article on the Southeastern Interlibrary Research Facility, of which he was the first director, appeared in the last issue.

Until Mr. Harwell's arrival, Samray Smith, ACRL publications officer, is serving as interim executive secretary. 